Volume 1, Nomor 1, Juni 2020

P-ISSN: 2722-4937, E-ISSN: 2722-4961

Website: http: pasca-umi.ac.id/index.php/jms

This work is licensed under a Creative Commons Attribution 4.0 International License.

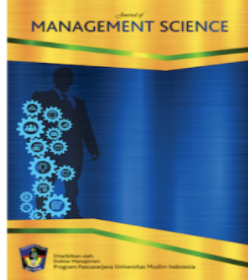

\title{
Pengaruh Tunjangan Kinerja, Motivasi Dan Disiplin Terhadap Kinerja Pegawai Kantor Otoritas Pelabuhan Utama Makassar
}

\author{
Mukhlis Abbe 1, A. Rahma Nuralam² \& \\ 1,2 STIE Lamappapoleonro Soppeng \\ ${ }^{2}$ Koresponden Penulis, E-mail: Mukhlis.abbas@stie.ypls.ac.id
}

\begin{abstract}
ABSTRAK
Hasil penelitian ini menunjukkan bahwa semua variabel, yaitu: Performance Allowanes, Motivasi dan Disiplin memiliki pengaruh positif dan signifikan secara simultan terhadap kinerja Otoritas Pelabuhan Kantor Utama Karyawan Makassar. Secara parsial ditemukan bahwa Motivasi faktorfaktor yang memiliki pengaruh signifikan terhadap kinerja Pegawai Paling dominan Kantor Otoritas Pelabuhan Makassar.
\end{abstract}

Kata kunci: Performance Allowanes, Motivasi dan Disiplin; kinerja karyawan

\begin{abstract}
The results of this study indicate that all the variables, namely: Performance Allowanes, Motivation and Discipline has a positive and significant effect simultaneously on the performance of the Port Authority Main Office Employees Makassar. Being partially found that the Motivation of factors that have a significant influence on the performance of the most dominant Employees Top Makassar Port Authority Office.
\end{abstract}

Keyword: Performance Allowanes, Motivation and Discipline; employee performance 


\section{PENDAHULUAN}

Berdasarkan data tahun ketujuh diberlakukannya Peraturan mengenai pemberian Kompensasi Tunjangan Prestasi Kerja (TPK) telah mampu memberikan manfaat yang positif bagi peningkatan produktivitas kerja PNS.Hal tersebut berbeda sekali dengan ketika Peraturan tersebut belum diberlakukan. Walaupun demikian, masih ada beberapa kendala yang penulis amati, antara lain penerapan disiplin pegawai saat ini hanya berdasarkan absensi manual, dimana keakuratan data masih dapat dimanipulasi dan tidak dapat dipertanggungjawabkan karena masih terdapatnya pegawai yang datang hanya untuk melalukan absen pagi lalu keluar dan kembali lagi pada siang serta sore hanya untuk menandatangani absen. Hal ini mempengaruhi kompensasi yang diterimanya, dimana adanya indikasi kecurangan antara pegawai yang hanya hadir untuk menandatangani absen dengan pegawai yang betul-betul bekerja sehingga mengakibatkan motivasi pegawai tersebut menjadi berkurang untuk menghasilkan output yang lebih baik, dimana akan berdampak buruk terhadap kinerja pegawai itu sendiri maupun organisasi.

Padahal pemberian Kompensasi Tunjangan Prestasi Kerja (TPK) ini diharapkan dapat memotivasi pegawai untuk menghasilkan prestasi kerja (kinerja) yang tinggi. Sehingga Pegawai Negeri Sipil (PNS) merasa puas karena telah terpenuhi kebutuhannya dengan mendapatkan kompensasi berupa Tunjangan Prestasi Kerja (TPK) sesuai dengan Jabatan maupun Pangkat/Golongan Ruang, maka akan tercapai kepuasan kerja dan memiliki komitmen kerja terhadap organisasi. Tingginya komitmen PNS dapat mempengaruhi Tunjang kinerja,Motivasi dan Disiplin PNS secara positif terhadap Kinerja pegawai.

\section{TINJAUAN PUSTAKA}

\section{Tunjangan kinerja}

Menurut Sidarmayanti $(2001 ; 23)$ "Kompensasi adalah segala sesuatu yang diterima oleh pegawai sebagai balas jasa untuk kerja mereka. Sedangkan menurut Simamora (2003; 442) Tunjangan adalah pembayaran dan jasa yang melengkapi gaji pokok dan perusahaan membayar semua atau sebahagian dari tunjangan ini. Salah satu bentuk dari kompensasi atau tunjangan adalah Tunjangan Kinerja.

Tunjangan Kinerja merupakan bentuk reward atau kompensasi yang diberikan atas kinerja pegawai/karyawannnya. Sesuai Peraturan Menteri Perhubungan No. 107 Tahun 2013 tentang tata cara Perhitungan dan Pemberian Tunjangan Kinerja Pegawai di Lingkungan Kementerian Perhubungan.

\section{Motivasi kerja}

Maslow mengemukakan suatu teori motavasi manusia yang menjelaskan suatu hirarki kebutuhan yang menunjukkan lima tingkatan kebutuhan dan keinginan manusia. Kebutuhan yang lebih tinggi mendorong seseorang untuk mendapatkan motivasi atas kebutuhan tersebut, setelah kebutuhan yang lebih rendah terpuaskan. 


\section{Disiplin}

Wursanto mengungkapkan disiplin adalah keadaan yang menyebabkan atau memberikan dorongan kepada pegawai untuk berbuat atau melakukan sesuatu kegiatan sesuai dengan norma-norma atau aturan-aturan yang ditetapkan. Siagian “ disiplin merupakan tindakan manajemen untuk mendorong para anggota.

Menurut Nainggolan disiplin adalah kondisi yang tercipta dan terbentuk melalui proses dari serangkaian prilaku yang menunjukkan nilai-nilai berhubungan dengan kepatuhan, ketaatan, kesetiaan seorang pegawai terhadap ketentuan, peraturan atau norma yang berlaku. Jadi disiplin dimaksud meliputi sikap seorang pegawai untuk selalu mentaati dan mematuhi peraturan yang berlaku serta setia dan taat kepada Negara dan pemerintah.

\section{KERANGKA KONSEPTUAL}

Kerangka konseptual adalah apresiasi terhadap pemikiran peneliti tentang pengembangan manajemen terhadap peningkatan kinerja, yang diadopsi dari konsep danteori yang mengacu kepada pentingnya pengembangan manajemen diterapkan dalam suatu organisasi, agar organisasi tersebut mampu melakukan persiapan kerja, perencanaan, pengorganisasian, pengkoordinasian dan pengawasan suatu aktivitas kerja yang sesuai dengan tugas pokok dan fungsi pegawai pada Kantor Otoritas Pelabuhan Utama Makassar

Lebih jelasnya dapat dilihat pada kerangka konseptual di bawah ini:

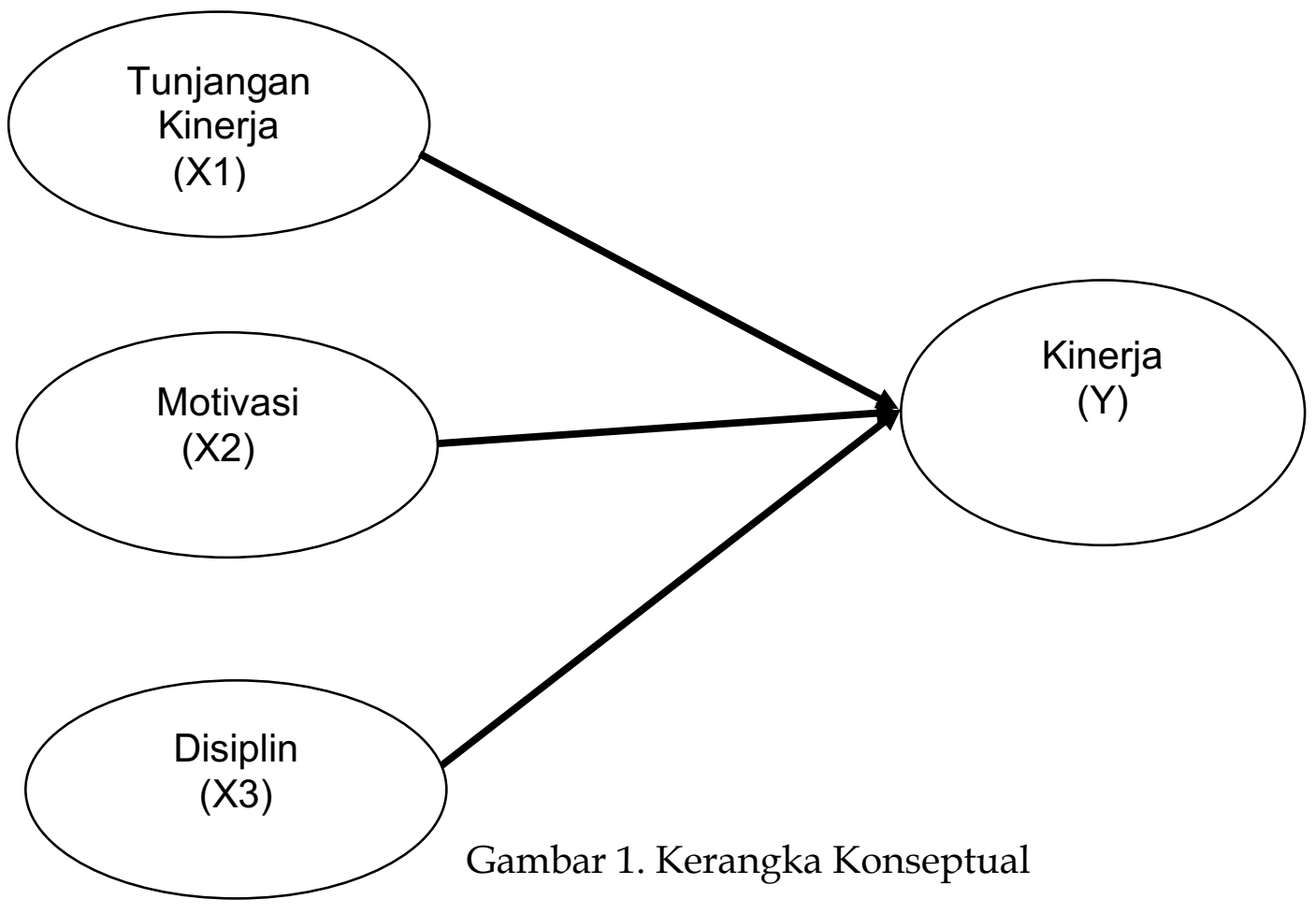




\section{HIPOTESIS}

1. Faktor Tunjangan Kinerja, motivasi dan disiplin berpengaruh positif dan signifikan terhadap kinerja pegawai kantor otoritas Pelabuhan Utama Makassar

2. Faktor motivasi merupakan variabel yang paling dominan pengaruhnya terhadap kinerja pegawai kantor otoritas Pelabuhan Utama Makassar

\section{METODE PENELITIAN}

\section{Pendekatan Penelitian}

Penelitian ini menggunakan tipe/pendekatan kuantitatif yang didasarkan pada aliran pemikiran posivistik dengan proses penelitian yang bersifat deduktif. Dengan pendekatan ini, diharapkan hasil yang diperoleh di lokasi sample penelitian dapat dijadikan sebagai generalisasi terhadap populasi yang telah ditetapkan.

\section{Waktu dan lokasi penelitian}

Penelitian dilakukan dikantor otoritas Pelabuhan Utama Makassar. Lokasi ini dipilih karena didorong oleh keinginan untuk mengetahui faktor yang mempengaruhi kinerja pegawai kantor otoritas Pelabuhan Utama Makassar. Adapun waktu yang digunakan dalam penelitian ini kurang lebih tiga bulan lamanya.

\section{Populasi dan Sampel}

Metode pengambilan sampel yang digunakan dalam penelitian ini adalah metode sensus, yaitu teknik pengambilan sampel dimana semua anggota populasi yang jumlahnya 100 orang dijadikan responden

\section{Metode Analisis Data}

Untuk menguji hipotesis yang telah diajukan dalam penelitian ini, maka digunakan metode analisis:

1. Analisis secara deskriptif yaitu menganalisa pengaruh pengembangan SDM terhadap kinerja pegawai pada kantor otoritas Pelabuhan Utama Makassar

2. Metode analisis regresi linier berganda untuk menganalisis pengaruh pengembangan SDM terhadap kinerja pegawai pada kantor otoritas Pelabuhan Utama Makassar dengan rumus: (Soemarsono, 2005:47)

$$
Y=b_{0}+b_{1} X_{1}+b_{2} X_{2}+b_{3} X_{3}+e_{i}
$$

$$
\begin{array}{ll}
\text { Dimana: } \\
\mathrm{Y} \quad=\text { Kinerja pegawai } \\
\mathrm{X}_{1} \quad=\text { Tunjangan kinerja } \\
\mathrm{X}_{2} \quad=\text { Motivasi kerja } \\
\mathrm{X}_{3} \quad=\text { Pengalaman kerja } \\
\mathrm{b}_{1}-\mathrm{b}_{3}=\text { Koefisien Regresi (Parameter) } \\
\mathrm{b}_{0} \quad=\text { Konstanta (Intercept) } \\
\mathrm{e}_{\mathrm{i}} \quad=\text { Faktor Kesalahan }
\end{array}
$$

Selanjutnya untuk menentukan pengaruh dan tingkat signifikan $\alpha=0.05$ atau 5\% diuji dengan menggunakan uji-F dan uji-t melalui program komputer SPSS 17.0. 


\section{HASIL PENELITIAN DAN PEMBAHASAN}

\section{Hasil Penelitian}

Berdasarkan pada hasil uji asumsi klasik menunjukkan bahwa regresi berganda yang diestimasi telah memenuhi syarat asumsi-asumsi klasik sehingga diharapkan hasilnya akan baik dalam menganalisis pengaruh dari variabel independent terhadap variabel dependent. Pengujian terhadap hasil regresi yang diperoleh dilakukan pengujian secara serempak dengan menggunakan uji-F dan pengujian secara parsial dengan menggunakan uji-t. Maka dapat diuraikan untuk lebih jelasnya:

1. Pengujian Hipotesis Secara Serempak

Tabel 1 Pengujian Secara Simultan (Uji-F)

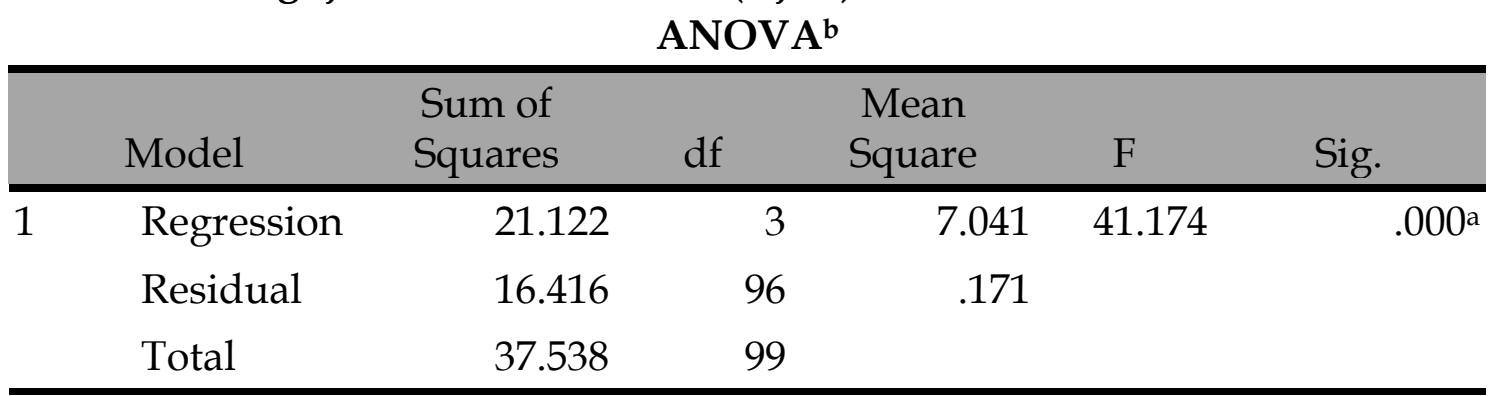

a. Predictors: (Constant), Disiplin, Tunjangan kinerja, Motivasi

b. Dependent Variable: kinerja pegawai

\section{Pengujian Hipotesis Secara Parsial}

\section{Tabel 2 Pengujian Secara Parsial (Uji-t)}

Coefficients ${ }^{a}$

\begin{tabular}{|c|c|c|c|c|c|c|}
\hline & & $\begin{array}{l}\text { Unstandardi } \\
\text { Coefficients }\end{array}$ & & $\begin{array}{l}\text { Standardize } \\
\text { d } \\
\text { Coefficients }\end{array}$ & & \\
\hline & & B & Std. Error & Beta & $\mathrm{t}$ & Sig. \\
\hline 1 & (Constant) & .049 & .508 & & .097 & .923 \\
\hline & $\begin{array}{l}\text { Tunjangan } \\
\text { kinerja }\end{array}$ & .248 & .097 & 172 & 2.542 & .013 \\
\hline & Motivasi & .394 & .069 & .475 & 5.715 & .000 \\
\hline & Disiplin & .360 & .084 & .356 & 4.297 & .000 \\
\hline
\end{tabular}

a. Dependent Variable: kinerja pegawai

Selanjutnya pada tabel 13, dapat diketahui bahwa hasil persamaan regresi linier berganda dari model penelitian ini adalah sebagai berikut :

$Y=-0,049+0,248 X_{1}+0,394 X_{2}+0,360 X_{3}$

Besarnya kontribusi yang diberikan dari variabel,tunjangan kinerja,motivasi dan Disiplin terhadap kinerja Pegawai Kantor Otoritas Pelabuhan Utama Makassar dapat 
dilihat dari koefisien determinasinya. Perolehan nilai determinasi $\left(\mathrm{R}^{2}\right)$ dapat dilihat pada tabel dibawah ini :

Tabel 14 Hasil pengujian Koefisien Determinasi $\left(\mathbf{R}^{2}\right)$ Model Summary

\begin{tabular}{rrrrr}
\hline Model & R & R Square & Adjusted R Square & Std. Error of the Estimate \\
\hline 1 & $.750^{\mathrm{a}}$ & .563 & .549 & .41352 \\
\hline
\end{tabular}

a. Predictors: (Constant), Tunjangan kinerja, Motivasi,Disiplin

\section{Pembahasan}

Berdasarkan tujuan penelitian ini yakni untuk mengetahui dan menganalisis pengaruh tunjangan kinerja, motivasi dan disiplin terhadap Kinerja pegawai Kantor Otoritas Pelabuhan Utama Makassar. Setelah dilakukan pengujian hipotesis penelitian ini, maka ketiga variabel bebas yakni: tunjangan kinerja, motivasi dan disiplin berpengaruh positif dan signifikan terhadap Kinerja pegawai Kantor Otoritas Pelabuhan Utama Makassar. Penelitian ini secara serentak atau bersamasama ketiga variabel bebas terhadap variabel terikat yang menunjukkan pengaruh positif dan singnifikan yang dibuktikan dengan besarnya kontribusi $\left(R^{2}\right)=0,563$ atau 56,3\%. Artinya Kinerja pegawai Kantor Otoritas Pelabuhan Utama Makassar dapat diprediksikan bahwa untuk meningkatkan Kinerja pegawai perlu menggunakan ketiga variabel bebas tersebut. Sedang adanya sisa menunjukkan bahwa masih perlu mencari variabel yang belum dapat teridentifikasi dalam penelitian ini, sehingga bagi para peneliti selanjutnya.

1. Pengaruh Tunjangan kinerja terhadap kinerja pegawai

Berdasar analisis hasil penelitian ini menunjukkan bahwa Tunjangan Kinerja yang dimiliki setiap pegawai berpengaruh positif dan signifikan terhadap Kinerja pegawai. Besarnya pengaruh tunjangan kinerja terhadap peningkatan kinerja pegawai disebabkan karena tunjangan kinerja yg sy terima telah sesuai dengan kelas jabatan, penentuan besarnya tunjangan kinerja yg diberikan kepada pegawai sesuai dengan tingkat pendidikan, pembayaran tunjangan kinerja selalu tepat waktu, pembayaran tunjangan kinerja yang diberikan telah sesuai berdasarkan absensi,besarnya tunjangan kinerja yg diberikan dapat mencukupi kebutuhan hidup.Hasil analisis penelitian ini membuktikan bahwa tunjangan kinerja yang dimiliki oleh pegawai berpengaruh positif dan signifikan terhadap kinerja pegawai yang dapat dibuktikan dengan besaran nilai sumbangannya melalui nilai kontribusi $\left(\beta_{1}\right)=0,248$ atau $24,8 \%$ dan juga dapat diperlihatkan melalui hasil signifikansinya yakni thitung $=2,542$ dengan probabilitas $=0,013<0,05$, menunjukkan bahwa jika tunjangan kinerja pegawai dapat ditingkatkan, maka akan dapat meningkatkan Kinerja pegawai

Temuan hasil penelitian ini sejalan dengan temuan hasil penelitian Liza Hardani 2016 yang menemukan bahwa tunjangan kinerja berpengaruh positif dan signifikan terhadap kinerja pegawai negeri sipil Negeri Sipil Balai Karantina Pertanian Kelas I Banjarmasin. Mendukung hasil penelitian Muh. Yunus (2012) "Pengaruh Kompensasi, Motivasi dan Disiplin Tehadap kinerja pegawai negeri sipil Kepolisian Negara Republik Indonesia Daerah Sulawesi Selatan" bahwa faktor kompensasi, 
motivasi dan disiplin memiliki pengaruh yang positif dan signifikan secara simultan terhadap kinerja pegawai negeri sipil pada Kantor Kepolisian Negara Republik Indonesia Daerah Sulawesi Selatan. Sedangkan secara parsial factor kompensasi yang memiliki pengaruh signifikan yang paling dominan terhadap kinerja.

2. Pengaruh motivasi kerja terhadap kinerja pegawai

Hasil penelitian ini menunjukkan bahwa jika kelima indikator yang melekat dalam motivasi kerja pegawai mendapat peningkatan perhatian dan dapat diwujudkan dengan baik, maka semangat kerja pegawai akan lebih meningkat. Hal ini perlu menjadi perhatian yang lebih besar oleh pimpinan agar setiap pegawai dapat memiliki integritas yang tinggi dalam menjunjung nama baik organisasi dan dapat melaksanakan tugas yang lebih professional terutama dalam menjaga nama baik lembaga.

Hasil analisis penelitian ini membuktikan bahwa motivasi kerja yang dimiliki oleh pegawai berpengaruh positif dan signifikan terhadap kinerja pegawai yang dapat dibuktikan dengan besaran nilai sumbangannya melalui nilai kontribusi $\left(\beta_{2}\right)=0,394$ atau $39,4 \%$ dan juga dapat diperlihatkan melalui hasil signifikansinya yakni thitung $=$ 5,715 dengan probabilitas $=0,000<0,05$, menunjukkan bahwa jika motivasi kerja pegawai dapat ditingkatkan, maka akan dapat meningkatkan Kinerja pegawai

3. Pengaruh Disiplin Terhadap Kinerja pegawai

Dari hasil pengujian menunjukkan bahwa secara simultan disiplin berpengaruh secara signifikan terhadap kinerja pegawai Kantor Otoritas Pelabuhan Utama Makassar, Hal ini dibuktikan dari nilai koefisien beta dengan hasil tersebut memperkuat pendapat dari beberapa ahli dan peneliti terdahulu

Kenyataan yang ditemukan pada pegawai, tidak dapat disangkali bahwa banyak pegawai yang tidak disiplin dalam mematuhi komitmen terhadap aturan kerja, khususnya yang berkaitan dengan tingkat kehadiran pegawai dalam bekerja, ketepatan waktu dalam menyelesaikan pekerjaannya, kepatuhan terhadap peraturan dan tidak adanya sanksi kerja yang menyebabkan pegawai sering melakukan kelalaian, pelanggaran tentang ketentuan disiplin kerja.

\section{KESIMPULAN}

1. Secara simultan ketiga variabel bebas, yakni tunjangan kinerja,motivasi dan Disiplin berpengaruh positif dan signifikan terhadap kinerja pegawai pada Kantor Otoritas Pelabuhan Utama Makassar. Oleh karena itu, hipotesis penelitian ini diterima.

2. Secara parsial tunjangan kinerja berpengaruh positif dan signifikan terhadap kinerja pegawai pada Kantor Otoritas Pelabuhan Utama Makassar ..

3. Terdapat pengaruh positif dan signifikan secara parsial antara motivasi kerja dengan kinerja pegawai Kantor Otoritas Pelabuhan Utama Makassar

4. Terdapat pengaruh positif dan signifikan secara parsial antara lingkungan kerja dengan kinerja pegawai Kantor Otoritas Pelabuhan Utama Makassar . 
5. Faktor Motivasi paling dominan pengaruhnya terhadap kinerja pegawai Kantor Otoritas Pelabuhan Utama Makassar.

\section{SARAN}

Sesuai hasil dan pembahasan serta kesimpulan penelitian yang telah dikemukakan sebelumnya, maka ada beberapa hal yang perlu disarankan, atau direkomendasikan kepada pimpinan manajemen pada Kantor Otoritas Pelabuhan Utama Makassar, yaitu:

1. Untuk meningkatkan dan memelihara kinerja pegawai terutama dalam hal tunjangan kinerja pegawai yang diberikan sebagai penghargaan terhadap kinerja pegawai sesuai dengan beban kerja yang diberikan

2. Untuk meningkatkan dan memelihara kinerja pegawai terutama dalam hal pengawasan, maka manajemen perlu melakukan upaya pengembangan sumberdaya manusia melalui pendidikan dan pelatihan.

3. Untuk lebih meningkatkan kinerja pegawai pada Kantor Otoritas Pelabuhan Utama Makassar maka masih perlu bersikap dan berperilaku yang ditunjukkan sebagai bagian dari dorongan atau dukungan yang berasal dari dalam dan luar diri pegawai.

4. Perlu memberikan ruang kerja yang baik kepada pegawai, baik lingkungan fisik maupun non fisik yang mampu meningkatkan kenyamanan dan keamanan pegawai dalam menjalankan tugas dan pekerjaannya sehingga dapat mencapai tujuan lembaga yang maksimal

\section{DAFTAR PUSTAKA}

Abimayu, Anggito 2000. Analisis Kompetensi SDM. Penerbit Andi, Yogyakarta.

Arifin, Anwar, 2000. Kinerja dan Pelayanan Publik. Penerbit Rineka Cipta, Jakarta.

Akba, 2000. Kompetensi Pegawai. Gunung Agung, Jakarta.

A.Irwansyah (2008). Pengaruh Kompetensi Sumberdaya Manusia terhadap Kinerja Customer Service Pada PT Bank Negara Indonesia (Persero) Tbk Kota Makassar

Barata Adya Atep, 2004, Dasar Dasar Pelayanan Prima, edisi ke dua,Penerbit PT Elex Media Komputindo, Gramedia Yakarta. 